The EU as a Normative Power and the Research on External Perceptions: the Missing Link

Larsen, Henrik

Published in:

Journal of Common Market Studies

DOI:

10.1111/jcms.12109

Publication date:

2014

Document version

Publisher's PDF, also known as Version of record

Document license:

Unspecified

Citation for published version (APA):

Larsen, H. (2014). The EU as a Normative Power and the Research on External Perceptions: the Missing Link. Journal of Common Market Studies, 52(4), 896-910. [13]. https://doi.org/10.1111/jcms.12109 


\title{
The EU as a Normative Power and the Research on External Perceptions: The Missing Link*
}

\author{
HENRIK LARSEN
}

University of Copenhagen

\begin{abstract}
In research on European foreign policy two important axes of debate have been running relatively independently of each other for more than a decade: the study of the European Union as a normative power (NPE) and the study of external perceptions of the EU. However, the studies of external perception offer some findings that are central for the NPE debate. This article's argument is that the external perceptions literature points to a limited (if still identifiable) perception of the EU as a normative power depending on the geographical area. By comparison, the image of a powerful economic actor is prevalent. The article raises the question of whether the thin and geographically varied character of the perceptions relating to the EU as a normative power justifies the general designation of NPE. A new agenda focusing on geographical differences and interaction with other sources of power is outlined.
\end{abstract}

\section{Introduction}

In research on European foreign policy, two important axes of debate have been running for more than a decade. ${ }^{1}$ The most prominent one has been the study of the European Union as a normative power (Normative Power Europe, NPE) launched by Manners (2002). The other is the study of external perceptions of the EU conducted in three major research projects led, respectively, by Chaban and Holland, Lucarelli and Elgström (see Chaban et al., 2013; Lucarelli and Fioramonti, 2010; Chaban and Holland, 2008; Elgström, 2007). The two fields have given rise to a voluminous literature in journals, books and other channels. However, the two axes of discussion have been running relatively independently of each other. This is surprising because the views of the outside world would seem to be relevant for the discussion about whether the EU is a special normative power. References to NPE can be found in the literature on perceptions of the EU (but not the other way round) where it is stressed that the findings have relevance for the discussion about the EU as a normative power. A recent article takes up the issue of NPE as one of the elements examined (Chaban et al., 2013). Even so, there have been no systematic analyses of the importance of international perceptions for whether the EU can be characterized as a normative power.

Some recent work on NPE attempts to clarify the necessary assumptions of what power means in the debate about it. Among other things, it looks at the importance of the

\footnotetext{
*The author would like to thank the Department of Political Science at the University of Auckland, New Zealand, for its hospitality during the writing of this article in January-May 2013.

${ }^{1}$ This is, of course, not to suggest that these have been the only important axes of debate and research.
} 
discursive or status context for whether the EU can be said to be a normative power (Forsberg, 2011; Keene, forthcoming; Larsen, forthcoming). One central argument in this literature is that the precondition for the EU to be a special normative power is that the outside world attributes a distinct role to the Union. However, this literature on NPE has not engaged with empirical studies on how the outside world looks at the EU.

The starting point of this article is that studies of external perceptions of the EU offer some findings that are helpful for the debate about whether the EU can be considered a normative power. The main argument is that the literature points to a limited (if still identifiable) perception of the EU as a normative power depending on the geographical area. By comparison, the image of a powerful (and not always benevolent) economic actor is prevalent. From this background, the article raises the question as to whether the thin and geographically varied character of the perceptions relating to the EU as a normative power justifies the general designation of NPE.

The article first outlines some central points in recent discussions on NPE with special reference to the conceptualization of power. It then goes on to present the main findings in the literature on external perceptions of the EU. Finally, the implications of the external perceptions literature for the discussion about NPE are discussed.

\section{Normative Power Europe: The Importance of the Context of Meaning ${ }^{2}$}

Since its launch by Manners in 2002, the concept of 'normative power' has fruitfully generated a debate about the possibly unique role of the EU in international relations. The concept has been a source of inspiration in empirical analyses for a significant number of scholars - not least due to the openness of its central formulations (Huells, 2011, p. 87). Criticism of the concept and the inherent claim that the EU is a 'normative power' have also been raised as part of the debate about NPE. ${ }^{3}$

On the basis of constructive critique of the concept of NPE, attempts have been made to modify it, often focusing on different analytical connotations of NPE or particular aspects of the EU's external activity. Here, the concept has been refined, inter alia, by adding the notion of the EU as 'ethical power'. The debate focuses on whether the EU's discourse about itself as a 'power for good' is in accordance with its actions (Aggestam, 2008). The discussion about NPE runs parallel to the literature about the older idea of the EU as a civilian power launched by Duchêne in the early 1970s during the cold war, in which the Union is considered special in its use of civilian means and civilian aims (Duchêne, 1972). At present, NPE is generally seen as more analytically interesting than 'Civilian Power Europe' (Forsberg, 2011, p. 2; Bachman, 2013, p. 19). A related concept is Nye's idea of soft power, presented in the early 1990s, which is about the general attractiveness of units in international relations. Soft power is broader than NPE as it looks at the attractiveness of society, economy, political institutions, values and so on, and the implications for the power of a unit (Nye, 2004, ch. 1).

In the discussion about NPE less attention has been paid to analyzing Manners' understanding of power and discussing whether another or a more nuanced understanding of power would enhance the value of the concept of normative power. The understanding of power is always a central part of any concept within international relations (Guzzini,

\footnotetext{
${ }^{2}$ Parts of the argument in this section draw on Larsen (forthcoming).

${ }^{3}$ For a list of the relevant texts by Manners and an overview of the criticism, see Forsberg (2011).
} 
2005, p. 508). A power can basically mean a unit with certain capabilities or characteristics attached; in the case of NPE, the EU is seen as a unit that, in some sense, is based on norms. The nine norms mentioned in Manners (2002, pp. 242-3) are peace, liberty, democracy, rule of law, human rights plus the 'minor norms' of social solidarity, antidiscrimination, sustainable development and good governance. In addition, (normative) power can also be understood as the power exercised by this unit vis-à-vis the outside world (cf. Forsberg, 2011, pp. 8-9). This article focuses on this second sense of (normative) power - the exercise of power - as opposed to the understanding of a power as a unit with certain characteristics as it is not viewed as particularly fruitful since all states or other units can be said to have a normative foundation of some kind that affects their foreign policies (Diez, 2005).

Central to Manners' understanding (and thus in line with the view of power as the exercise of power in relation to the outside world) is the "ability to shape conceptions of what the "normal" is' in international relations (Manners, 2002, pp. 239-40). In political science, power is often theorized in terms of four dimensions. The first dimension, often associated with Dahl (1957), is the ability of A to get B to do something that B would not otherwise have done. The second dimension is A's ability to prevent an issue from reaching the decision-making agenda (Barach and Baratz, 1963). The third dimension is 'the power to shape, influence or determine others' beliefs and desires, thereby securing their compliance' (Lukes, 2005b, p. 486). The fourth dimension is based on Foucault's radical critique of conceptions of power in terms of the first three dimensions. Here, it is the social context within which social actors are embedded that ascribes certain roles and possibilities to the actors. Power is not the property of particular individuals, classes or states; all social actors and relationships are subjects of power (Lukes, 2005a, pp. 88-9). Power is in this sense both productive and oppressive. Differently from the first three dimensions of power, there is no conception of actors' 'objective' interests. There is also less of an interest in the overt exercise of power, and more of an interest in general patterns of domination.

Manners (2002) and subsequent work is not explicit about his understanding of power. However, the six mechanisms for the diffusion of norms presented in Manners (2002, pp. 244-5) suggest that his concept of power is restricted to or, at least, concentrates on, the exercise of power in terms of the third dimension and, to a lesser extent, the first dimension (Huells, 2011, p. 88). His mechanism of 'transference' falls within Dahl's first dimension of power and is thus not different from the way states are often seen to further their own views. His mechanisms of 'contagion', 'informational', 'procedural' and 'overt' diffusion all come with examples of how EU norms are passed on to the outside world in specific situations (Manners, 2002, pp. 244-5), but there are no considerations about the broader structural context that leads the outside world to adopt these norms. Only the mechanism of 'cultural filter' suggests a broader interest in why the outside world might (or might not) adopt EU norms. Manners' reference is to Kinvall's (1995, pp. 61-71) treatment of 'cultural filter'. However, Kinvall's work is about how norms are read through particular constructions of knowledge and identity, not about a particularly favourable context for EU norms. Manners gives no clear suggestions about the nature of the processes whereby other states might be prone to adopting the EU's norms as part of a 'cultural filter'. The often quoted formulation that 'the most important factor shaping international role of the EU is not what it says or does, but what it is'(Manners, 2002, 
p. 252) is about the driving forces of EU actions, not about the EU's structural position. Since the usage of the first and third dimensions of power in imposing norms would not make the EU different from the way other international actors further their norms (cf. Diez, 2005), Manners' conceptualization of power is not helpful for examining how the EU is in a unique category as an international actor that shapes conceptions of the normal. If we want to look at whether the EU influences conceptions of the normal in international relations, a more structural conception of power is more appropriate - a notion of the power of an actor that looks at the context of meaning in which the actor is embedded.

By looking at how particular structures of meaning provide the EU with an ability to influence the normal (Manners, 2002, pp. 242-3), we are going beyond the six mechanisms presented in Manners. Such a broadening of the understanding of power through the inclusion of the contextual preconditions is not incompatible with Manners' ambition to examine the shaping of conceptions of the normal by the EU. And it is in line with the tendency in the tradition of constructivism to which Manners broadly belongs to embrace the fourth dimension of power (Guzzini, 2005, p. 495). ${ }^{4}$

For the EU to have the status of a normative power regionally or globally, the international actors have to find that the EU plays a special role in defining the normal or as a beacon for norms. If international actors do not view the EU in this way, or only to a limited extent, then the EU is not likely to be able to influence conceptions of the normal in international politics through normative power. ${ }^{5}$ It is important to note that it is not necessarily an either/or question. The EU may be a normative power in some geographical or functional contexts and not in others. Moreover, if the EU's norms are part of a dominant discourse so that the EU's norms strike a chord, then the EU is more likely to be able to influence conceptions of the normal as a normative leader (Larsen, forthcoming).

A way of looking at the importance of the context of meaning is to take a sociological approach to the contextual elements of NPE. The EU's putative normative power can be viewed as based on status in a stratified international society. Such an approach is in line with recent arguments for introducing sociological considerations about stratification into international relations (Buzan and Albert, 2010). ${ }^{6}$

In an important contribution, Keene (forthcoming) draws on this approach to make the argument that the EU is a normative power today. His point of departure is that imperial European states in the 19th century had normative power. This was because Europe had a high status in international society partly based on culture. The Europeans built and promoted a certain standard of civilization against 'barbarism'. According to Keene, 'one reason for the relatively high prestige that attaches to the EU's "normative difference" in international relations today is that it still draws on the legacy created in the nineteenth century' (Keene, forthcoming, p. 13). The EU is seen as 'drawing on cultural capital that has gradually been accumulated over 200 years before its foundation' (Keene, forthcoming, p. 14). However the EU's normative power today is also different from the

\footnotetext{
${ }^{4}$ Due to the background of the NPE argument in constructivism, this article conceptualizes the structural context in terms of meaning structures. A power political/economic understanding of structures would not make it possible to examine a distinct source of normative power.

${ }^{5}$ A parallel line of reasoning is Laïdi's call for a reflection on reception theory applied to Europe (Laïdi, 2008, p. 18).

${ }^{6}$ This article does not draw on the diffusion approach of Börzel and Risse (2009) or Acharya (2009), as the former primarily works with the first three dimensions of power and the latter focuses on Asian institutions.
} 
19th-century European normative power. The Union's normative power today relies on the promotion of values such as human rights and liberty and competence in the economic, environmental or diplomatic field rather than symbolic indicators of identity and status (Keene, forthcoming, p. 15). As moral knowledge and technical competence can be acquired by other international actors, the exceptionalism that contributes to the EU being a normative power is fragile (Keene, forthcoming, pp. 14-16).

Two points can be raised against Keene's argument. First of all, it is not a given that the putative status of the former colonial powers is translated into EU normative power today. The EU itself does not have the imperial past that would allow for a historical 'mission civilisatrice'. Also, advocates of the EU as an alternative kind of power downplay references to Europe's imperial past (Bachmann and Sidaway, 2009, p. 104). Moreover, it is somewhat unclear which part of the complex 28 Member State institutional edifice would convey a former 'mission civilisatrice'. Secondly, through a postcolonial lens, the question is whether the European designation of itself as having a civilizing mission was ever widely seen as a legitimate background for shaping conceptions of the normal during the time of imperialism and whether that is the case today. The political resistance to colonialism and the subsequent attempts by the new states to assert themselves politically through groupings such as G77 and the non-aligned movement illustrate that Europe or the west are not seen as inherent leaders. The gap between the stated normative aims of the EU and the effects of the EU's economic actions in fields such as agriculture creates tensions that might weaken the overall perception of EU normative power (Bachman, 2013). The existence of an African Charter on Human Rights and the many defeats of the western countries in the United Nations Human Rights Council and General Assembly over the last ten years do not suggest that European norms are seen as particularly attractive or that the EU is viewed as a leader (Larsen, forthcoming). In the post-western world, the EU is one among many regional actors promoting its norms (Buzan, 2012).

In the following we will explore empirically, with the help of the external perceptions literature, whether the EU can be said to have a status as a normative power in line with Keene's general argument.

\section{The External Perceptions Literature}

Within the last five to ten years, growing attention has been paid to the external image of the EU. In addition to articles on particular (national) perceptions of the EU, ${ }^{7}$ three major research projects have provided general insight into external perceptions of it. The first systematic study of the external perceptions of the EU was carried out by researchers at the National Centre for Research on Europe (NCRE) at the University of Canterbury, New Zealand, where Holland and Chaban have played central roles (see, for example, Chaban and Holland, 2008). ${ }^{8}$ The focus is on Asia and the Pacific. The second project was undertaken within the Framework of Excellence, Garnet (Sixth European Framework Programme). It was led by Lucarelli and Fioramonti at the Forum of Problems of Peace and War in Florence, Italy (Lucarelli and Fioramonti, 2010). The third major research

\footnotetext{
${ }^{7}$ To my knowledge, no comprehensive list of these has been compiled. Many have been published in European Foreign Affairs Review.

${ }^{8}$ For a full list of publications, see «http://www.euperceptions.canterbury.ac.nz».
} 
project was Elgström's one on the perceptions of the EU in multilateral negotiations, 'New Roles for the EU in International Politics' (see, for example, Elgström, 2007). A recent article by Elgström and members of the NCRE synthesizes some of the findings from southeast Asia, the Pacific and Africa (Chaban et al., 2013).

Although the concept of NPE is taken up in these research projects, there is no in-depth treatment of how the external perceptions findings contribute to the literature on normative power more broadly. There are several stated reasons for this. First of all, the debate about the putative distinctiveness of the EU in terms of 'civilian', 'normative', 'structural' and so on is characterized as internal and too 'sterile' (too conceptual and not empirical) (Lucarelli, 2007, p. 252). Second, the debate about NPE is criticized for assuming that the EU's normative power is the result of the spread of universal values. The perceptions literature (in particular, the Garnet project) assumes, in line with role theory, that the EU shapes its own normative setting through its political actions and, in turn, that the external actors' perceptions (which are partly a result of the EU's actions) are important for what kind of international actor the EU is. This is why the empirical work on external perceptions is judged to be more important (Lucarelli, 2007, pp. 254-6; see also Chaban et al., 2006, pp. 248-9). The aim is also to contribute to diminishing the gap between the EU's self-perception and the perceptions of the outside world (Chaban and Holland, 2008).

NPE is taken up most directly in Chaban et al. (2013), which draws on 274 semistructured interviews with political, business, civil society and media elites in countries in southeast Asia (Philippines, Malaysia, Singapore, Thailand, Vietnam), Africa (South Africa and Kenya) and the Pacific region (Fiji, Papua New Guinea and wider Pacific) (Chaban et al., 2013, p. 17). The interviewees were asked what kind of great power the EU might be (military/economic/diplomatic and or normative?). The interpretation of the data is based on the assumption that normative influence is associated with soft power and the ability to persuade third parties to follow its policies or imitate its institutions (Chaban et al., 2013, pp. 434-5, 438).

In the next section, I will attempt to summarize the main findings of the research on the external perceptions of the elites, focusing on the elements that are relevant for the discussion of NPE. The assumption is that the elite dimension has the most direct relevance for the NPE discussion as it is the most closely linked to politics. It should be noted that the three main projects deal with different elite groups. Elgström's studies focus on international negotiators; Chaban and Holland's studies look at business, political, civil society and media stakeholders; and the Garnet studies deal with political elites. Chaban and Holland have also studied media perceptions and public opinion. Moreover, the different studies of elite views use different methods. Some are based on semi-structured interviews (see, for example, Chaban et al., 2013, Elgström, 2007), others analyze political documents (see, for example, Santini et al., 2010), and others combine these methods (see, for example, Murray, 2008). From a methodological point of view, then, the findings are not fully comparable. In a broader sense, the question is whether some of these methods are more suited than others for examining a structural conception of power such as status (Larsen, forthcoming). Nonetheless, the volume of the work undertaken on external perceptions, together with the fact that the results of the research point in the same direction in spite of the different methods used (see below), justify an engagement with this literature. 


\section{The Main Findings of Research on External Perceptions ${ }^{9}$}

In the following, the main findings of the three research projects and the individual articles are presented. First, an overall finding at a general level is that the EU is widely seen as an international actor across issue areas, but not as a great power in all fields (Chaban et al., 2013, pp. 444, 446). In relation to commercial issues and the environment, the EU is perceived as a great power (Elgström, 2007; Kilian and Elgström, 2010). The importance of the EU is often ranked after that of the United States and China (see, for example, Jain and Pandey, 2013). The lack of EU unity is also an important image in some parts of the world, although this is not the dominant perception (Chaban et al., 2013, pp. 446-7).

Second, the perception of the EU as an international economic power is predominant. To a large extent, the main image the EU casts of itself has to do with its economic might as a trade giant, a huge market and a source of direct foreign investment (Lucarelli, 2007, p. 265; Chaban et al., 2013, pp. 443-4; Olivier and Fioramonti, 2010, p. 116). Brussels is perceived as a key actor in the economic/social area, together with the G77 and the United States. It is frequently seen as playing a more positive role than the United States (Brantner, 2010, p. 171; Santini et al., 2010, pp. 55-7). Studies conducted after the onset of the economic crisis do not provide a significantly different picture (Chaban and Holland, 2012, pp. 7-8). Its role as an economic leader gives the EU status (Chaban et al., 2013 , p. 449). However, its economic power is not perceived in positive terms in many parts of the world. A negative image of the EU as an economic power is predominant in the south (Africa, the Pacific, southeast Asia, India, Brazil and China) and in Africa in particular. The EU appears as a powerful bloc and an unequal counterpart, which contributes to keeping Africa in a subordinate position (Chaban et al., 2013, pp. 442, 447; Olivier and Fioramonti, 2010; Sicurelli, 2010, p. 191). This negative image is based on what is seen as the EU's economic protectionist stance on agricultural products, its conditionality measures in trade agreements and its hard bargaining tactics during trade negotiations (Brantner, 2010: Morini et al., 2010, p. 41; Olivier and Fioramonti, 2010, p. 111; Fioramonti and Poletti, 2008). The EU's use of 'partnership' rhetoric in dealings with the ACP (Africa, Carribean, Pacific) countries in this context is seen as false (Elgström, 2010; Sheahan et al., 2010). Terms such as 'neo-colonialism' frequently appear in analyses of the views of the south on the EU as an economic power, and this also affects readings of NPE (Olivier and Fioramonti, 2010, pp. 116-17; Chaban et al., 2013, p. 447).

Third, the Union is seen as playing a role in the global political field. Here the south has a more positive image of the EU. There are seen to be qualitative differences between the EU and the United States with regard to democratic governance, multilateralism and so on, where the EU is seen as the more progressive ${ }^{10}$ But it is seen as a rather weak actor in the political field (Morini et al., 2010, pp. 37, 47), although the Union is viewed as having diplomatic power (Chaban et al., 2013). This refers to the EU's ability to use the carrot and stick, but also "a style of interaction "relatively more engaging than dictating", (Chaban et al., 2013, p. 445). It is not seen as a power in the military field (Chaban et al., 2013, p. 445), but is seen as playing a role in peaceful reconciliation or mediation (Chaban et al., 2013, p. 443; Bruter, 2008: Lucarelli, 2007). The Union is viewed as acting

\footnotetext{
${ }^{9}$ For an overview of perceptions of the EU in international institutions, see Lucarelli (2013).

${ }^{10}$ It should be noted that the analyses are from before the Obama presidency.
} 
positively on the basis of the experience of the European integration project (Olivier and Fioramonti, 2010, pp. 116-17).

Fourth, the image of the EU as an actor in the field of development is not prominent generally and is rarely quoted as bearing weight on the EU's stance in the world (Lucarelli, 2007). But the image of the EU as an important aid provider comes up in countries which are, to some extent, dependent on EU aid (Chaban et al., 2013, pp. 446-7). Somewhat surprisingly, the image of the EU as a leader in environmental issues is not prominent either (Chaban et al., 2013, p. 8; Lucarelli, 2007, p. 269).

\section{The External Perceptions Literature and Normative Power Europe}

The EU is not widely or predominantly seen as a 'normative power' with a special role and legitimacy in exporting the norms mentioned in Manners (2002). Chaban et al. (2013, p. 443), who summarizes some of the Elgström/NCRE findings on elites, conclude that:

A considerable number of our respondents perceived the EU as a leader either generally or in certain areas. [...] However, its leadership qualities reside primarily in economics and commercial fields including development assistance. This applies across regions. A much smaller number of interviewees characterized the EU as a political and sometimes normative leader through promoting human rights (South Asia), supporting democracy through conditionality (Pacific, Kenya) and crisis prevention (Africa). The EU was seldom viewed as a leader in security or environmental issues.

The overall result of the Garnet project takes the same line. It is concluded that:

We could not find much evidence of the EU being widely seen as a 'normative power', exporting universal values of democracy and human rights. Equally surprisingly, the EU no longer seems to be regarded as a social model to be imitated [. . . the external image of the EU is not one of great distinctiveness, except perhaps in a few areas such as [...] the EU model of regional integration. Elements of distinctiveness emerge also as far as the EU's approach to crisis management is concerned. (Lucarelli, 2007, p. 269; see also Fioramonti and Lucarelli, 2010, p. 222)

The common denominator across the projects is the prevalence of an image of the EU as a leader in the economic field. The Elgström/NCRE study detects elements of normative power perceptions even if they are by no means prominent, whereas the Garnet project (in its summaries) detects few if any. These are significant findings for the debate about NPE.

Going through the different regions of the world, the normative dimension is characterized as 'completely absent' in interviews in the Pacific while it is 'somewhat visible' in Africa and southeast Asia together with the environmental and developmental dimensions, according to Chaban et al. (2013, p. 444). In quantitative terms, the EU was characterized as a normative power the most by political elites interviewed in the Philippines (approximately 20 per cent of those interviewed), whereas no interviewees in the Pacific categorized the EU as a normative power (Chaban et al., 2013, p. 445).

In the Garnet studies, the EU is not viewed as a normative power in Brazil, China, India, Russia or South Africa (Morini et al., 2010; Olivier and Fioramonti, 2010). ${ }^{11}$ The

\footnotetext{
${ }^{11}$ Thus the findings in Garnet and Chaban et al. differ somewhat on South Africa. See also below.
} 
Union is not conceived as a normative power in the United States, where it is often viewed in terms of its Member States rather than as a unit (Sperling, 2010). For Australian elites, the image of the EU as a normative power does not feature clearly. The Australian elite shows little understanding of how the EU projects a view of itself as a guardian of global governance and trade norms; the image of an economic power is dominant (Murray, 2008). The image of an economic power is also dominant in New Zealand, although the EU is seen as an important partner (but not a role model) in many political areas, and its historical, political and cultural links to New Zealand are given weight (Holland et al., 2005, pp. 7-8, 15). In Canada, the view of the EU as an economic actor is also dominant. Even if there are examples of the EU's measures in, for instance, human rights being mentioned in favourable terms in the Canadian parliament, this dimension is not strong (Croci and Tossutti, 2008). Generally speaking, there are few signs of the EU being seen as a normative power in the western world.

To the extent that the EU is referred to as having a special status, this is often through the example of the reconciliation and integration process in Europe - as a model for regional co-operation (Bruter, 2008). This is found in the cases of China, Russia and India (Jain and Pandey, 2013, pp. 337-8; Morini et al., 2010, p. 41), and arguably contributes to ascribing the EU a special status in peaceful international conflict resolution.

There are some important geographical exceptions to the conclusion that the EU is not predominantly seen as a normative power. Such perceptions are much more prominent in the EU's eastern and southern neigbourhoods. ${ }^{12}$ According to Bengtson and Elgström (2012, p. 99), Ukraine, Georgia, Armenia, Azerbaijan and Moldova (but not Belarus) 'readily recognize both the great power status of the EU and the attractiveness of its normative agenda. [...] the civilizing mission of the EU is perceived in positive [...] terms as a contribution to desirable transformation'. Among the general public in these countries, values such as human rights, democracy and freedom of speech are frequently associated with Brussels. The EU is seen as having contributed to developing democracy in these countries and human rights are viewed as an important area of co-operation; however, in line with the general picture, trade and economic development remain the areas where the most important role for the EU is envisaged (TNS, 2013, pp. 16, 18-22).

For Mexican elites, too, the EU is seen as a point of reference and a fundamental actor in the defence of human rights, democracy and multilateral institutions. 'The Mexican elite accepts the "moral" leadership of the EU on the international stage. [. . .] for Mexican political leaders the EU and Latin America have practically the same importance' (Chanona, 2010, p. 131; Carta, 2010, p. 213). In South Africa, 'the EU was sometimes credited with a critical role in the consolidation of democracy and peacekeeping as well as raising standards of health and social development' (Chaban et al., 2013, p. 442). Singaporean and Filipino elites recognized the EU's leading role in promoting human rights and democracy, presenting a 'better version of democracy' (Chaban et al., 2013, p. 442). Perceptions of the EU as a normative power are thus more prominent in the countries neighbouring the EU and in a few individual countries around the world.

Quite importantly, the general absence of images of the EU as a normative power takes three very different forms. One variant is that the EU is not understood as having a special

\footnotetext{
${ }^{12}$ Findings in the southern neighbourhood are based on surveys of the general public. To my knowledge, no studies of elite perceptions of the EU after the Arab Spring have been carried out yet.
} 
role in the normative field as it is not normatively different or superior, but is a political partner. The NPE label is sometimes met with puzzlement. This is the view that is found in the western world. A second variant is that the EU is seen as promoting certain legitimate norms. However, the EU's promotion of these norms is not viewed as credible as it is interpreted as a cover for attempts to exercise neo-colonial political control (cf. Chaban et al., 2006, p. 261; Carta, 2010, p. 213). The neo-colonial reading of the EU's actions, whatever their declared intentions, means that no space is opened up for seeing the EU as a unit connoting universal norms; the Union is almost seen as a negative normative power! For example, in an analysis of interviews with 11 diplomats at the UN (nine non-western), Brantner (2010, pp. 175-6) shows that the EU's leadership role in human rights is recognized. However, its overall impact is limited by the general reading through a 'neo-colonial lens'. Third World diplomats do not believe that neo-colonial aims are altered just by EU Member States acting together, even if their motives are not quite as suspicious as those of the United States.

The EU focus on human rights is frequently seen as a way of settling political scores - to regain neo-colonial control. As a diplomat from Singapore said during a UN debate about the death penalty: "The EU wanted everybody to think the way they did. When their values "shift", our values must also "shift" (quoted in Brantner, 2010, p. 172; see also Chaban et al., 2013, p. 446). The EU was also accused of double standards: the Union singles out countries for condemnation in cases where the price of attack is not high (Brantner, 2010, pp. 172-3). In Iran, liberals see the EU's normative agenda as driven by its own economic agenda rather than by the promotion of democracy (Santini et al., 2010, pp. 55-7).

The sustainable growth element of normative power also clashes with what is seen as the EU's de facto actions in the economic field. Issues such as free trade, non-tariff barriers and agricultural subsidies produce an image of the EU as an actor that perpetuates neo-colonial domination (Fioramonti and Poletti, 2008, pp. 177-8). At the same time, we can also find nuances in the neo-colonial interpretation in the form of the understanding that the EU can be of help in the promotion of certain norms. The African Union (AU) officially shares the EU's concern for human rights, but asserts that the Africans have to solve things themselves (Sicurelli, 2010, pp. 189-90).

The third variant is that the EU does not promote legitimate universal values. The Union's promotion of certain norms is understood as an expression of Eurocentrism and clashes with the views of other parts of the world (cf. Chaban et al., 2006, p. 261; Carta, 2010, p. 213). The EU is attempting to further its own norms in common with most other international actors. The Chinese and Russian elites share this view and thus are negatively disposed towards the EU's critical approach to human rights issues and democracy, seeing it as interference in internal political affairs (Morini et al., 2010, p. 41). The view of sovereignty as taking precedence over human rights is also one that has gained ground in the UN for the last ten years (Gowan and Brantner, 2008). The position of the Organization of Islamic Conferences that defamation of religion is a threat to human rights, put forward in the UN Human Rights Commission for the last 10-15 years, is also an expression of how the EU's basic view of human rights is not universally accepted.

In summary, an image of the EU as a normative power can be found in its neighbourhood and in individual countries around the world, but, in general terms, the perception of the EU as an economic power is the dominant image. The general absence of an image of 
the EU as a normative power comes in three forms. The first presents the EU as a partner with no special normative status. The second sees the EU as a self-declared promoter of legitimate norms, but views this as an attempt by the EU and its former colonial powers to reintroduce neo-colonial control. A third sees the EU as a power that attempts to further its own norms rather than universal norms. In the three readings, the EU does not have a special status through its norms which might give it influence. To the extent that there is a component of EU normative power connotations that is widely accepted, it is the 'peace' element. The EU's status as a mediator or reconciler is viewed in less ambivalent, and more positive, terms than the rest of Manners' nine norms. It should be added that the research on external perceptions focusing on public opinion and the media corroborates this picture in general terms (see, for example, Chaban and Holland, 2012, p. 8; Chaban, 2011, pp. 14-18).

\section{So What? Implications for the Debate about Normative Power Europe}

The findings of the research on external perceptions have significant implications for the debate about NPE as argued in the following six points. First of all, normative power, as understood in the theoretical section, cannot be considered to be the primary way in which the EU exerts international influence today. The perception of the EU as a normative power is clearly secondary to the perception of economic power. This is not a problem in itself for the NPE concept: Manners (2002, p. 239) pointed out in his original article that the EU's normative power coexisted with other and more traditional kinds of power. But it does indicate that the NPE dimension cannot be the predominant source of power for the EU.

Second, there are significant geographical differences in the extent to which the EU is seen as a normative power. This perception of the EU is much more prominent in the EU's southern and eastern neighbourhood and much weaker or non-existent in the rest of the world. Future debate about NPE has to take this crucial geographical element into account. The EU is not a global normative power - even if it attempts to promote its norms globally. In this light, it is interesting to note that NPE was launched at a time when the EU was at its most successful in terms of shaping understandings in the field of human rights and other fields in relation to the enlargement to the east. This may provide part of the background for why NPE, to a large extent, has been a debate by Europeans for a European audience (Tocci, 2008, p. 21). The image of the EU as a normative power is the strongest in countries which hope to obtain closer links with the EU - and possibly membership. The perceived importance of EU normative status within and around Europe was not, and is not, shared by the rest of the world. It is the EU's economic power that stands out more than anything else.

Third, the finding that significant parts of the elites in the world - many parts of Africa, China, Brazil - feel that the EU is using its strong economic position to protect its own neo-colonial interests, rather than providing a special kind of help to the Third World, has implications for the discussion about NPE. The perception of the EU seems closer to Hill's (1990) term 'power bloc' and the neo-colonial lens keeps in check the NPE reading.

Fourth, even where perceptions of elements of normative power are present, the way in which its normative status is read often places limits on the extent to which the EU can 
'influence conceptions of the normal'. In many countries and contexts, the normative arguments are not accepted because they are put forward by the EU even if the Union is sometimes accepted as a carrier of legitimate norms! Again, the neo-colonial lens keeps in check the NPE reading.

Fifth, the research on external perceptions does not provide support for Keene's suggestion that the EU's normative power rides on its status as a civilized family of nations in the 19th century and the creator of the post-1945 order through the UN Charter. Certainly, the elements of normative power status that can be found could be related to Keene's argument, but given the expectations arising from the fundamental long-term elements that Keene brings up, there is not much evidence of a widespread normative status. The normative status of the EU is weaker or non-existent in the former European empires where a critical image of a neo-colonial EU dominates. An economic interpretation would stress that the EU's dictating of the terms of trade and development policy through a structural, instrumental policy (Holden, 2009) is behind the critical image of the Union as primarily a neo-imperial power projection. From this perspective, Europe's economic and political activities, past and present, override the importance of its historical status. The relative absence of normative power perceptions of the EU in old colonies such as the United States (which does not have a strong image of the EU), Canada, Australia and New Zealand does not lend itself easily to a similar structural economic analysis. The EU is the number one trade partner for the United States (and vice versa), the second biggest export market for Canada and Australia, and the third biggest export market for New Zealand. The latter three countries do not have the same relative importance for EU trade. The relatively strong economic position of the EU vis-à-vis these countries can possibly explain why the economic image is dominant, but not the weak image of the EU's normative role. Criticism of EU trade practices in an unequal relationship can certainly be found in Australia and New Zealand, but links are usually not made to EU inconsistency in the political/normative field or political domination via European norms (Murray, 2008; Holland et al., 2005). If anything, Keene's point about how the EU's normative status is fragile (as it is not unique) may be a more relevant explanation, with many western states claiming to be based on the same values as the EU (and therefore refusing human rights suspension clauses in joint agreements with the Union). The stronger perception of the EU as a normative actor in its neighbourhood cannot be linked to structural economic patterns in a simple way either. If anything, the link is the opposite from the countries where the neo-colonial interpretation is dominant: adaptation of the EU's norms is part and parcel of economic development.

Finally, the comparative angle should be brought in. It may be that the EU does, in some contexts, have power to shape conceptions of the normal through its status or cultural capital, but an actor such as the United States has that (mixed) status as well. Surveys of the United States' global image show that about 50 per cent of the global population view American democratic values and customs in a positive light. ${ }^{13}$ It may thus be that the EU has a degree of normative power through international perceptions, but that it is not a special actor in this respect. If this is so, it is not obvious why the debate about normative power should revolve around the EU.

\footnotetext{
${ }^{13}$ Pewglobal: «http://www.pewglobal.org/2012/06/13/chapter-2-attitudes-toward-american-culture-and-ideas/».
} 


\section{Conclusions}

This article has presented an analysis of the concept of NPE based on the literature on external perceptions of the EU. On this background, it was questioned whether the use of the term 'NPE' as a general analytical label for the EU was justified. Given the international context of meaning, the label 'regional normative power' may be more appropriate for the EU. The analysis points to two suggestions for a continued, but narrower, analytical focus on NPE. First, attention has to be paid to the geographical context and policy area where EU normative power is relevant. This would include the limited group of countries where perceptions of NPE are prominent. Second, given that NPE is never the only perception of the EU or, indeed, the most prominent one, future analyses have to consider how the EU's normative power might work in combination with other sources of power in the countries where significant NPE perceptions can be found.

\section{Correspondence:}

Henrik Larsen

Department of Political Science

University of Copenhagen

Øster Farigmagsgade 5

1014 Copenhagen K

Denmark

email: HL@ifs.ku.dk

\section{References}

Acharya, A. (2009) Whose Ideas Matter? Agency and Power in Asian Regionalism (Ithaca, NY: Cornell University Press).

Aggestam, L. (2008) 'Introduction: Ethical Power Europe?' International Affairs, Vol. 84, No. 1, pp. 1-11.

Bachman, V. (2013) 'The EU's Civilian/Power Dilemma'. Comparative European Politics, Vol. 11, No. 4, pp. 1-23.

Bachmann, V. and Sidaway, J. (2009). 'Zivilmacht Europa: A Critical Geopolitics of the European Union as a Global Power'. Transactions of the Institute of British Geographers, Vol. 34, No. 1, pp. 94-109.

Barach, P. and Baratz, M. (1963) 'Decisions and Non-decisions: An Analytical Framework'. American Political Science Review, Vol. 57, pp. 641-61.

Bengtson, R. and Elgström, O. (2012) 'Conflicting Role Conceptions? The European Union in Global Politics'. Foreign Policy Analysis, Vol. 8, pp. 93-108.

Börzel, T. and Risse, T. (2009) 'The Transformative Power of Europe: The European Union and the Diffusion of Ideas'. KFG Working Paper 1. Available at: «http://userpage.fu-berlin.de/kfgeu/ kfgwp/wpseries/WorkingPaperKFG_1.pdf».

Brantner, F. (2010) 'The EU through the Eyes of the United Nations: The Quest for Unity'. In Lucarelli, S. and Fioramonti, L. (eds).

Bruter, M. (2008) 'Europe from Within, Europe from Without: Understanding Spontaneous Perceptions of the EU in the Asia-Pacific'. In Chaban, N. and Holland, M. (eds) The European Union and the Asia-Pacific: Media, Public and Elite Perceptions of the EU (London: Routledge).

Buzan, B. (2012) 'The Inaugural Kenneth N. Waltz Annual Lecture - a World without Superpowers: Decentered Globalism'. International Relations, Vol. 25, No. 1, pp. 3-25. 
Buzan, B. and Albert, M. (2010) 'Differentiation: A Sociological Approach to International Relations Theory'. European Journal of International Relations, Vol. 16, No. 3, pp. 315-37.

Carta, C. (2010) 'Close Enough? The EU's Global Role Described by Non-EU Diplomats in Brussels'. In Lucarelli, S. and Fioramonti, L. (eds).

Chaban, N. (2011) 'The EU's Imagery as Social, Developmental and Environmental Actor'. EU External Affairs Review, Vol. 2, pp. 5-23.

Chaban, N. and Holland, M. (2008) 'Introduction'. In Chaban, N. and Holland, M. (eds).

Chaban, N. and Holland, M. (2012) 'Europe in Times of Crisis: Perceptions from the Asia-Pacific'. Regional Integration Observer, Vol. 6, pp. 6-8.

Chaban, N., Elgström, O. and Holland, M. (2006) 'The European Union as Others See It'. European Foreign Affairs Review, Vol. 11, pp. 245-62.

Chaban, N., Elgström, O., Kelly, S. and Yi, L. (2013) 'Images of the EU beyond Its Borders: Issue-Specific and Regional Perceptions of European Union Power and Leadership'. JCMS, Vol. 51, No. 3, pp. 433-51.

Chanona, A. (2010) 'So Far, So Close? Mexico's Views on the EU'. In Lucarelli, S. and Fioramonti, L. (eds).

Croci, O. and Tossutti, L. (2008) 'That Elusive Object of Desire: Canadian Perceptions of the EU'. European Foreign Affairs Review, Vol. 12, No. 3, pp. 287-310.

Dahl, R. (1957) 'The Concept of Power'. Behavioral Science, Vol. 2, pp. 201-15.

Diez, T. (2005) 'Constructing the Self and Changing Others: Reconsidering "Normative Power Europe". Millennium, Vol. 33, pp. 613-36.

Duchêne, F. (1972) 'Europés Role in World Peace'. In Mayne, R. (ed.) Europe Tomorrow (London: Fontana).

Elgström, O. (2007) 'The EU in International Trade Negotiations'. JCMS, Vol. 45, pp. 94969.

Elgström, O. (2010) 'Partnership in Peril? Images and Strategies in EU-ACP Economic Partnership Agreement Negotiations'. In Lucarelli, S. and Fioramonti, L. (eds).

Fioramonti, L. and Lucarelli, S. (2010) 'Self-Representations and External Perception: Can the EU Bridge the GAP?' In Lucarelli, S. and Fioramonti, L. (eds).

Fioramonti, L. and Poletti, A. (2008) 'Facing the Giant: Southern Perspectives on the European Union'. Third World Quarterly, Vol. 29, pp. 167-80.

Forsberg, T. (2011) 'Normative Power Europe Once Again: A Conceptual Analysis of an Ideal Type'. JCMS, Vol. 49, pp. 1183-204.

Gowan, R. and Brantner, F. (2008) A Global Force for Human Rights? An Audit of European Power at the UN (London: European Council of Foreign Relations).

Guzzini, S. (2005) 'The Concept of Power: A Constructivist Analysis'. Millennium, Vol. 33, pp. $495-521$.

Hill, C. (1990) 'European Foreign Policy: Power Bloc, Civilian Model - or Flop?' In Rummel, R. (ed.) The Evolution of Europe as an International Actor: Western Europe's New Assertiveness (Boulder, CO: Westview Press).

Holden, P. (2009) In Search of Structural Power: EU Aid Policy as a Global Political Instrument (Aldershot: Ashgate).

Holland, M., Chaban, N., Bain, J., Stats, K. and Sutthisripok, P. (2005) 'EU in the Views of Asia-Pacific Elites: Australia, New Zealand and Thailand'. NCRE Research Series 5 (Canterbury: National Centre for Research on Europe).

Huells, H. (2011) Norms and Power: The European Neighbourhood Policy as Governmentality. $\mathrm{PhD}$ thesis, Department of Political Science, University of Copenhagen.

Jain, R.K. and Pandey, S. (2013) 'The Public Attitudes and Images of the European Union in India'. India Quarterly, Vol. 68, pp. 331-43. 
Keene, E. (forthcoming) 'Social Status, Social Closure and the Idea of Europe as a "Normative Power"'. European Journal of International Relations.

Killian, K. and Elgström, O. (2010) 'Still a Green Leader? The European Union's Role in International Climate Negotiations'. Cooperation and Conflict, Vol. 43, pp. 255-73.

Kinvall, C. (1995) 'Cultural Diffusion and Political Learning: The Democratization of China'. Lund Political Studies 88 (Lund: University of Lund).

Laïdi, Z. (2008) 'European Preferences and Their Perception'. In European Foreign Policy in a Globalised World (London: Routledge).

Larsen, H. (forthcoming) 'Normative Power Europe and the Importance of Discursive Context: The European Union and the Politics of Religion'. Cooperation and Conflict.

Lucarelli, S. (2007) 'The European Union in the Eyes of Others: Towards Filling a Gap in the Literature'. European Foreign Affairs Review, Vol. 12, pp. 249-70.

Lucarelli, S. (2013) 'Perceptions of the EU in International Institutions'. In Joergensen, K. and Laatikeinen, K. (eds) Handbook on the European Union and International Institutions (London: Routledge).

Lucarelli, S. and Fioramonti, L. (eds) (2010) The European Union as a Global Actor (London: Routledge).

Lukes, S. (2005a) Power: A Radical View (Basingstoke: Palgrave Macmillan).

Lukes, S. (2005b) 'Power and the Battle for Hearts and Minds'. Millennium, Vol. 33, pp. 477-93.

Manners, I. (2002) 'Normative Power Europe: A Contradiction in Terms?' JCMS, Vol. 40, No. 2, pp. 235-58.

Morini, M., Peruzzi, R. and Poletti, A. (2010) 'Eastern Giants: The EU in the Eyes of Russia and China'. In Lucarelli, S. and Fioramonti, L. (eds).

Murray, P. (2008) 'What Australians Think about the EU: National Interests in an International Setting'. In Chaban, N. and Holland, M. (eds).

Nye, J. (2004) Soft Power: The Means to Success in World Politics (New York: Public Affairs).

Olivier, G. and Fioramonti, L. (2010) 'The Emerging "Global South": The EU in the Eyes of India, Brazil and South Africa'. In Lucarelli, S. and Fioramonti, L. (eds).

Santini, R., Mauriello, R. and Trombetta, L. (2010) 'Taking the Lead: EU Mediation Role Assessed by Iran and Lebanon'. In Lucarelli, S. and Fioramonti, L. (eds).

Sheahan, L., Chaban, N., Elgström, O. and Holland, M. (2010) 'Benign Partner or Benign Master? Economic Partnership Agreement Negotiations between the European Union and the Pacific Islands'. European Foreign Affairs Review, Vol. 15, pp. 347-66.

Sicurelli, D. (2010) 'Perceptions and Criticisms at the African Union'. In Lucarelli, S. and Fioramonti, L. (eds).

Sperling, J. (2010) 'American Elite Perceptions of Italy as a Foreign Policy Actor: Does Italy Figure into American Foreign Policy Calculations?' Modern Italy, Vol. 15, No. 3, pp. 259-76.

TNS (2013) EU Neighbourhood Barometer, Autumn 2012. Available at: «http://euneighbourhood .eu/wp\%20content/uploads/2013/03/Presentation6009ENPIwave2_event20march1.pdf».

Tocci, N. (2008) 'Profiling Normative Foreign Policy: The European Union and Its Global Partners'. In Who is a Normative Foreign Policy Actor? The European Union and Its Global Partners (Brussels: Centre for European Policy Studies). 
Copyright of Journal of Common Market Studies is the property of Wiley-Blackwell and its content may not be copied or emailed to multiple sites or posted to a listserv without the copyright holder's express written permission. However, users may print, download, or email articles for individual use. 